\title{
Performance Improvement Model Of Civil Servant At General Election Commission
}

\author{
Ikhvan Fuady, Ritha F Dalimunthe, Elisabet Siahaan \\ Study Management Faculty of Economic and Business \\ University of Sumatera Utara, Medan, Indonesia \\ ikhvan_imm@yahoo.com
}

\begin{abstract}
Each institution has always wanted a quality human resources as a valuable asset that is being sought and maintained. To get optimal results, organizations must be able to optimize factors that influence employee performance. Factors can increase employee performance are the extent to which human resource development and environmental work in an institution. This research aims to optimize human resource empowerment and work environment in the General Election Commission of North Sumatra Province so that it can produce the civil servants performance. The purpose of this study was to determine and analyze the influence of human resource empowerment and work environment on the civil servants performance in General Commision Election (GEC) of North Sumatra Province with job satisfaction as a moderating variable. The research is descriptive quantitative and nature of the research is descriptive explanatory. Data collection is done through interviews, documentation and survey with questionnaires to 45 respondent which spread to all civil servants in General Commision Election of North Sumatra Province with saturated sampling methods. Data analysis method used is multiple linear regression using SPSS software. Results of the study show the first models of human resource empowerment and environment simultaneously positive and significant effect on the performance of civil servants of General Commision Election of North Sumatra Province. Partially each human resource empowerment and the work environment positive and significant impact on the performance of civil servants of North Sumatra Provincial Election Commission. Human resource empowerment becomes a dominant factor in improving performance compared to work environment. Results of the second model showed that job satisfaction is not as moderating variabel thet effect human resource empowerment and the work environment on the performance of civil servants.
\end{abstract}

Keywords: Human Resources Empowerment, Work Environment, Job Satisfaction, Civil Servants Performance

\section{INTRODUCTION}

\section{A. Research Problem}

Employee performance is a work activity which expected from an employee and how well they are carried out. Humans as an element in the organization has a significant influence on the development of the organization. Humans who work for the organization is decisive for good or bad an organization running in peak at the organization's goals. The results achieved in achieving the objectives of the organization is also called the performance.

Every state's institution as an organization are expected to manage and regulate aspects of resources to achieve well categorized performance. The General Election Commission (GEC), as a state's institution that specialized in general elections in Indonesia, GEC had a significant role in a country which embraces democracy. The success of the elections of course, very relevant to the advancement of the Human Resources (HR) election organizer. Hopefully, the General Election Commission (GEC) can be a role model for countries in Asia, even the world, to learn democracy.

Employee performance problems at the General Election Commission of North Sumatra Province based from the author 
observations is still a lot of civil servants underemployed is lack of involvement of some employees in the assignment and work there. Empowerment of employees not maximized so that the workload becomes heavy. GEC of North Sumatra Provincial is a working unit that can not be said to be a shortage of Civil Servants. But the number of existing employees are not all optimally empowered. Subdivision which have many jobs and a high workload apparently only had fewer staff than in the other subdivision that have fewer workload.

A good working environment is a supporting factor that also considered to be very supportive in improved performance. This is a major concern for the General Election Commission of north Sumatra Provincial in each of the activities. General Election Commission of north Sumatra Provincial office buildings that exist today is still an asset of the regional government of North Sumatra province, so that the condition of the office building is not much to change, but only modified. The building that can not have a major modification affect the working environment.

A points of the performance of the General Election Comission is the number or percentage of community participation in local elections. The higher the number of community participation in using their voting rights, the greater the success of the Commission as an organizer. GEC North Sumatra province has a role in monitoring and supervision in every stage in the implementation of the local elections in the district / city of North Sumatra province.

Conditions voter turnout this decline can also be drawn in the picture as follows:

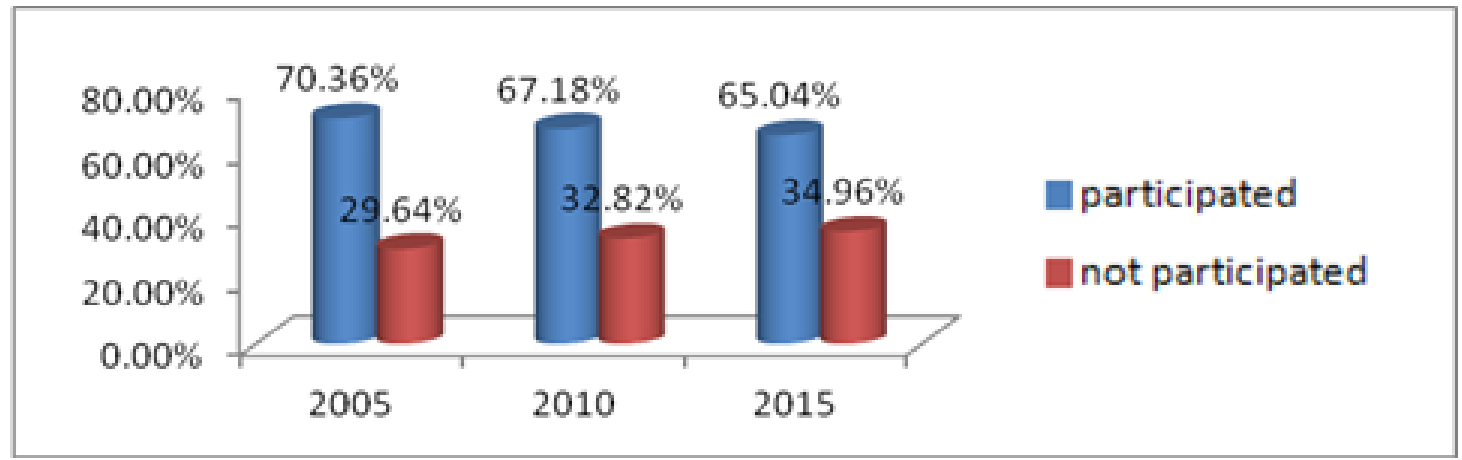

Figure 1. Community Participation in Local Election of North Sumatera Province

The voter turnout in the elections is one performance indicator of the General Election Commission, so that the success in increasing participation becomes very important. Explanation of the Commission's performance indicators outlined in the Government Performance Report (LAKIP) of GEC compiled tiered in every level from the Central Election Commission, Provincial GEC until the Regency / City GEC. LAKIP prepared after the end of each year. This report are made before the commencement of the performance agreements document which is used as a tool to measure the performance of the GEC.
Civil servant Performance as a supporting staff of GEC have a strategic role in improving the performance of institutions. Civil servant has a function as an adminstratif staf and technical personnel in carrying out any work into the institution's performance. All technical and administrative work of the Commission's civil servant, form the basis for a good or bad result of the GEC's performance at all levels ranging from the Central Election Commission, Provincial Election Commission to level the Regency / City. As one example where the number the decline participation of the voters, certainly due to various factors, including the performance 
of the General Election Commission itself. For that, the performance of civil servants that working in the General Election Commission would have to be optimized by correcting the flaws in the Commission's own institution.

\section{B. Employee Performance}

Performance is the result of work achieved in executing the tasks assigned to them based on skills, experience, seriousness and the time (Hasibuan, 2006). In another sense, the performance of the work results that can be achieved by a person or group of people in the organization, according to the authority and responsibility in order to attempt to achieve organizational goals (Prawirosentono, 2008).

An important role in an organization depends on the performance of employees. So that employees can work as expected, then the inside of an employee must be grown motivation to work to achieve everything you want. When morale is high then all the work assigned to employees will be more quickly and accurately completed.

\section{Job Satisfaction}

Kaliski in Aziri, (2011) mentions that, Job satisfaction is ever-increasing needs from time to time and people are always trying with all his ability to satisfy these needs. Perceived job satisfaction is directly related to the productivity of an employee in a work which implies the spirit and happiness at work. Therefore Job satisfaction reflects a person's feelings toward his work, this is a positive impact on employee attitudes toward work and everything encountered in the work environment. Department or management personnel should always monitor job satisfaction because it affects the attitude of presence, labor turnover, job satisfaction and other important things. Job satisfaction can be defined as a pleasant or unpleasant of employees in view of his work. It can be concluded that job satisfaction is the feeling of someone in their work, which can be influenced by various factors, both internal factors and external factors.

\section{Empowerment of Human Resources}

Employees are the main asset of a company and one of the production factors of the companies, but employees also have a strategic function in the delivery of concepts (Suryadewi et al 2014). Therefore it takes concepts that are giving more respect to human beings. Organizations must be able to empower and lead the human resources to their maximum in order to create job satisfaction which can impact in increasing human performance in the organization so that the organizations can be strong and competent. Employee performance issues can not be separated from their reward for a job or task positions held by employees. This situation eventually led to one of the concepts that empower employees.

Sedarmayanti (2010) states that: Empowerment is widely defined as more empowered than ever both in terms of authority, responsibility and the ability of the individual possesses. Human Resources is defined as the power that comes from humans or can be called a power or force (energy or power) that attached to the man himself in the sense of having the ability (competency), namely: knowledge (knowledge), skills (skills) and attitude (attitude).

\section{E. Work Environment}

The work environment is defined as everything that is around those workers which can influence him in carrying out the tasks entrusted (Weol 2015). work environment is everything that can give effect to the employees in the move and act, both directly and indirectly in carrying out the activities and it have an influence on the course of a good working system within a company.

The working environment consists of two types. First, the working environment concerning the physical aspect, which is everything that related to the physical aspect in the work environment. Second, the working 
environment that concerned in terms of psychological work environment that can not be captured by the five senses (Dharmawan, 2011). The working environment is the circumstances and conditions that give a sense of security and comfort in work, which is supported by the facilities in terms of physical form and in terms of psychological support that is the attitude of the workers.

\section{F. Conceptual Framework}

The government institutions should pay attention to proper management of its human resources in order to improve its performance. Each institutions or organization has the vision and mission of the company. To be able to carry out an effective mission used to achieve a vision therefore required a productivity which is essential in any organization, whether in public or private organizations. Employee productivity can be improved through a variety of ways, including through the empowerment of human resources by providing opportunities, capabilities and protection to the employee in performing their duties and responsibilities.

Arianto (2013) describes the factors that affect the performance of the employee is working environtment. environmental factors that affect the working environment is coloring, cleanliness, lighting, ventilation, music, safety and noise. The work environment can create working relationships that bind the people who are in the same work environment. Working environtment should be conducive to make employees feel comfortable when in working place and feel excited to perform his duties. This condition can form job satisfaction. If job satisfaction can be created, the performance of employees will also increase.

Companies can also create a pleasant working atmosphere in the sense that there is a good relationship between employees, between employees and leaders, as well as maintaining the health, safety in the work space so it will cause employee productivity. Therefore, job satisfaction can encourage employees to do more efforts for the company. Job satisfaction can moderate the employee in improving performance through perceptions of the work environment and the empowerment of human resources. Based on previous exposure, the conceptual framework of this research was formed as follows:

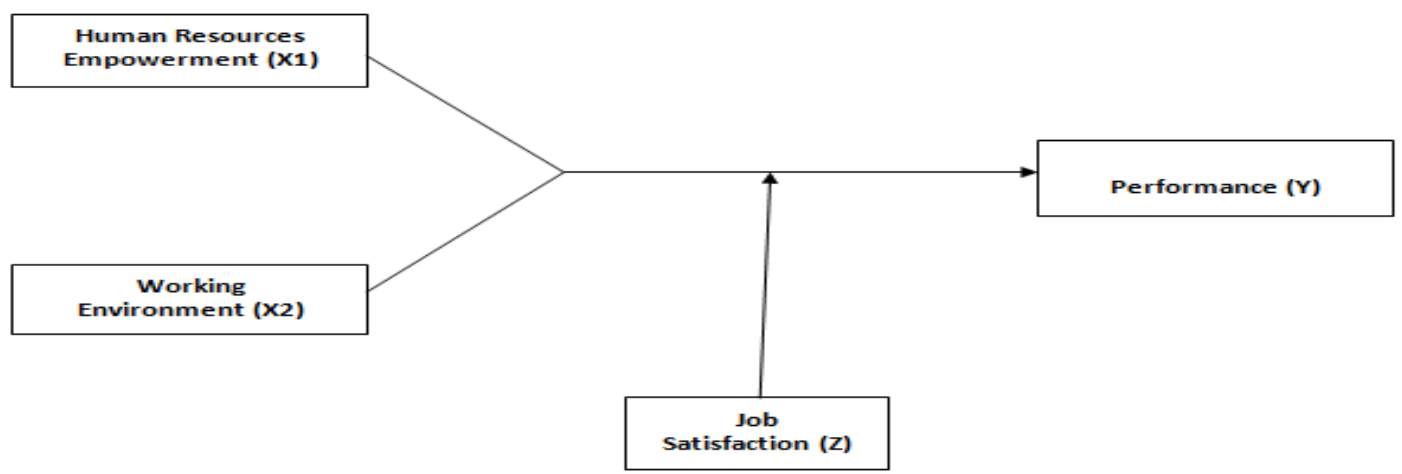

Figure 2 Conceptual Frame

The hypothesis of evaluating the conceptual framework are:

1. The Empowerment of Human Resource has significant effect on the performance of the Civil Servant

2. The working environment has a significant effect on the performance of civil servants.
3. Job satisfaction moderated the influence of empowerment of human resources's effect on the civil servant performances.

4. Job satisfaction moderated the influence of Work Environment's effect on the civil servant performance. 


\section{RESEARCH METHODS}

\section{A. Research Location and Time}

The study was conducted in March and July 2016. The study is located in north Sumatra GEC office, Jalan Perintis Kemerdekaan no. 35 Medan, North Sumatera.

\section{B. Population and Sample Research}

North Sumatera Provincial General Election has 45 employees. If fewer than 100 , it would be better if the samples taken as a whole, and this research is also called the research with a saturated sample (Arikunto, 2010).

\section{Data Collection Techniques}

In this study, data were collected by structured questionnaires distributed by the researchers. questionnaire is compiled based on theoretical studies related to the study variables. Before distributed, the questionnaires levels of validity reliability were tested. The questionnaire was prepared by forming a closed statement from the theory. Research questionnaire measuring perceptions of respondents to the statement filed with the 7 point Likert scale.

\section{Data Analysis Techniques}

\section{D.1 Descriptive Statistics}

Descriptive statistics were used to measure the level or the value of each variable in the actual research. This analysis helps understand the current situation on the object of research and to develop constructive suggestions.

\section{D.2 Statistics Inferential}

Inferential statistics are intended to know the relationship between the study variables. Relationships between the study variables can confirm theories and hypotheses proposed in this study. The study wanted to test the moderating influence of job satisfaction in building employee performance. Moderating effects evaluation method by using interaction test between independent variables with a moderating variable in forming the dependent variable. In a test of the interaction, this research use two sub models, without interaction models and models with interaction

Model without interaction is defined as:

$$
Y=\beta_{0}+\beta_{1} X_{1}+\beta_{2} X_{2}+e
$$

\section{Where :}

$$
\begin{array}{ll}
\mathrm{Y} & =\text { Performance } \\
\mathrm{X} 1 & =\text { Empowerment HR } \\
\mathrm{X} 2 & =\text { working environment } \\
\mathrm{a} & =\text { Constant } \\
\beta 1, \beta 2 & =\quad \text { Regression }
\end{array}
$$

coefficients

$$
\mathrm{e}=\text { error }
$$

Models with interaction is defined as:

coefficient $\beta$

$$
\begin{aligned}
& Y=a+b_{1} X_{1}+b_{2} X_{2}+b_{3} X_{3}+ \\
& b_{4} X_{1} X_{3} b_{5} X_{2} X_{3}+e
\end{aligned}
$$

Where :

$$
\begin{aligned}
& \mathrm{Y}=\text { Performance } \\
& \mathrm{X} 1=\text { Empowerment HR } \\
& \mathrm{X} 2=\text { working environment } \\
& \text { a }=\text { Constant } \\
& \beta 1, \beta 2, \ldots, 5=\text { regression }
\end{aligned}
$$

$$
\mathrm{e}=\text { error }
$$

\section{RESULTS AND DISCUSSION}

\section{A. Characteristics of Respondents}

This study involved all civil servants working at north sumatra general election commission, which there were 45 employees with a composition of 26 men $(57.8 \%)$ and 19 women (42.2\%). The recruitment process of civil servant at general election commission does not distinguish opportunities both for men and women which it supports the empowerment of human resources. The age of employees are in the range of 33 to 41 years old which is the age of mature employees at once productive work experience in carrying out his duties. This becomes a distinct advantage for the 
organization.

\section{B. Descriptive Statistics Result}

On the average score ratings of empowerment of human resources variable is 4.89 with an average category of slightly agree $(\min =4.53$, mean $=4.89, \max =$ 5,31 ). This indicates that the perception of the civil servant is quite good but there is still a lot of evaluation to be done in the empowerment of human resources in the North Sumatra GEC.

Assessment of the work environment variable result an average 4.34 with an average slightly agree $(\min =3.69$, mean $=$ 4.34, $\max =5.18$ ). Ratings indicate $\mathrm{a}$ positive response to the statement of the work environment. This indicates that it is still difficult for employees to feel that the working environment which they occupy is pleasant or adequate.

Assessment of the job satisfaction variable is at an average score of 5.27 ( $\mathrm{min}$
$=4.84$, mean $=5.27, \max =5,69$ ) indicating that although not very satisfy, the employees in general, have started to claim that he was satisfied with their work.

Assesment of the employee performance variables give the perception of the average value of 5.25 with the category slightly agree $(\mathrm{min}=4.31$, mean $=$ 5.25 , $\max =5.91$ ). Although classified as slightly agree, respondents are more inclined to the perceptions that their performance is already good.

\section{Infrensial Statistic Result}

C.1 Sub Model Structural 1

The results of the first sub structural model is the evaluation of the model without the job satisfaction moderating influence. The results of this analysis are summarized in Table 1.

Table 1 Coefficient Regression Model Without Moderation

\begin{tabular}{|l|c|c|c|c|c|}
\hline \multicolumn{3}{|c|}{$\begin{array}{c}\text { Unstandardized } \\
\text { Coefficients }\end{array}$} & \multicolumn{3}{c|}{$\begin{array}{c}\text { Standardized } \\
\text { Coefficients }\end{array}$} \\
\hline Model & B & Std. Error & Beta & t & Sig. \\
\hline (constant) & 3.471 & .164 & & 5.475 & .000 \\
\hline HR Empowerment & .228 & .101 & .312 & 2.255 & .029 \\
\hline $\begin{array}{l}\text { Working } \\
\text { Environement }\end{array}$ & .181 & .080 & .312 & 2.258 & .029 \\
\hline \multicolumn{2}{|l|}{ Dependent Variable : Performance } & & & \\
\hline
\end{tabular}

The results of the structural variables 1 forming linear equations to performance as the following:

$$
\mathrm{Y}=3,471+0,228 \mathrm{X} 1+0,181 \mathrm{X} 2+\varepsilon
$$

Human resource development and work environment provides a positive and significant influence in shaping the performance of employees. Furthermore, human resource development provide more dominant influence in building employee performance. Without the influence of the independent variable, at least the employee is still able to give a good performance with a constant value of 3.471 .

\section{C.2 Sub Model Structural 2:}

The results of the evaluation of the structural II sub models is an evaluation model with the job satisfaction moderating influence. The results of this analysis are summarized in Table 2. 
Table 2 Coefficient Regression Model With Moderation

\begin{tabular}{|c|c|c|c|c|c|}
\hline \multicolumn{3}{|c|}{$\begin{array}{l}\text { Unstandardized } \\
\text { Coefficients }\end{array}$} & \multicolumn{3}{|c|}{$\begin{array}{l}\text { Standardized } \\
\text { Coefficients }\end{array}$} \\
\hline Model & B & Std. Error & Beta & $\mathrm{t}$ & Sig. \\
\hline (constant) & 4.909 & 3.499 & & 1.403 & .169 \\
\hline HR Empowerment &,- 427 & .487 & -.583 & -.877 & .386 \\
\hline $\begin{array}{l}\text { Working } \\
\text { Environement }\end{array}$ & .283 & .449 & .486 & .629 & .533 \\
\hline Job Satisfaction & -.215 & .678 & -.339 & -.317 & .753 \\
\hline Mod 1 & .115 & .091 & 1.296 & 1.296 & .212 \\
\hline Mod 2 & -.023 & .088 & -.264 & -.256 & .799 \\
\hline
\end{tabular}

The results of the variables influence structural II provides performance-forming linear equation as follows:

$$
\begin{array}{r}
Y=4.909-0.427 X_{1}+0,283 X_{2}+ \\
0,215 X_{3}+0.115 X_{1} X_{3}-0.023 X_{2} X_{3}+\varepsilon
\end{array}
$$

In the sub-structure equation II there is no significant influence of the job satisfaction to employee performance. The result of this interaction provides an explanation that job satisfaction does not have a significant impact in forming the performance of employees. Moreover, job satisfaction has not been able to moderate the influence of the work environment and human resource development in forming the performance of employees.

\section{Key Findings and Discussion}

The results showed that the empowerment of human resources has a significant and positive effect to employee performance of general election commission of North Sumatra Province. The results are consistent with previous research conducted by Bagus Arga Saputro (2015) at GEC of Batu City where Human resource empowerment has an positif and significant effect in improving performance. In this study, the influenced of the human resources empowerment to performance can be seen from the results of employee's perceptions, especially at point statement regarding the suitability of an employee's skills based on experience, the majority of respondents feel agree with their jobs based on skills they have. the authority to use the facilities, the majority of respondents chose to agree with the high access granted to the employees in work.

The results showed that the Hypothesis of work environment has a positive and significant effect on the performance of employees is acceptable. This give conclusion that the work environment has a positive and significant effect on the performance variables. The results of this study support previous theories and other research such as a research by Weol (2015) which conducted at the Department of Education of North Sulawesi province where the work environment as one of the variables. Weol research showed that work environment have a positive and significant effect in improving the performance of civil servants.

Job satisfaction is not a variable that moderated the influence of human resource empowerment and work environment on the performance. This supports the results of previous research conducted by Baihaqi (2013) which states that job satisfaction variables not significant as moderating variables on performance. However, the research is also contrary to research conducted Yogi Andrianto (2008), where his thesis found the evidence of job satisfaction as variables that can moderate the performance. 
performance of the civil servant.

\section{CONCLUSION AND IMPLICATION}

Based on the results of research and discussion that has been described in the previous chapter, the conclusion can be formulated as follows:

1. Human resources empowerment partially have a positive and significant impact on the civil servant's performance of general election commission of North Sumatra Province..

2. The working environment is partially have a positive and significant impact on the civil servant's performance of the general election commission of North Sumatra Province. So we can use this variable to increase the civil servant performance.

3. Job satisfaction can not moderate the influence of human resource empowerment on the civil servant performance of general election commission of north sumatera province.

4. Job satisfaction cannot moderate the influence of work environment on the civil servant performance of general election commission of north sumatera province.

In accordance with research findings, we suggest that organization nowadays to be more focused on how to empower the Human resources more affectively. All the human resources in the organization will be more productive if the organization know the right job for each one of the employees and know how to put them in to the right position. The organization should be also equally distribute the task to all human resources available.

The organization should also develop the working environtment in the workplace. Good working environtment will bring a happy feeling to the employees and make them feel comfortable with their job. This two factors can produce the good

\section{FUTURE WORK}

This research discusses the factors that can influenced of civil servant performance of general election commissions. in order to develop employee performance more effectively and efficiently, it is expected there other studies that show a greater influence in forming the performance of civil servant. Moreover, job satisfaction in this study did not show a benefit in improving employee performance. It is have to be evaluated on whether job satisfaction itself is important for employees or not, because the presence of good regulation in evaluating performance or performance-based allowances is considered more effective to improve the civil servant performance and productivity.

\section{ACKNOWLEDGMENT}

The author would like to thank the General Election Commission of North Sumatera which permits the research as well as all staff who participated in this research. Hopefully, civil servant of general election of North Sumatra province have a greater improvement of their performance in the future.

\section{REFERENCES}

Arianto, Dwi Agung Nugroho. 2013. Pengaruh Kedisiplinan, Lingkungan Kerja Dan Budaya Kerja Terhadap Kinerja Tenaga Pengajar. Jurnal Economia, Vol. 9, No. 2.

Andrianto, Yogi. 2008. Analisis Pengaruh Partisipasi Penyusunan Anggaran Terhadap Kinerja Manajerial Dengan Kepuasan Kerja, Job Relevant Information Dan Kepuasan Kerja Sebagai Variabel Moderating. Semarang. Tesis. Universitas Diponegoro.

Any, Noor. 2013. Manajemen Event. Bandung : Alfabeta 
Arikunto, Suharsimi. (2010). Prosedur Penelitian "Suatu Pendekatan Praktik". Jakarta: Rineka cipta.

Aileen Mitchell Stwart. 1998. Empowering People, Pemberdayaan Sumber Daya Manusia. KANISIUS (Anggota IKAPI). Yogyakarta.

Arikunto, Suharsimi. 2010. Prosedur Penelitian Suatu Pendekatan Praktik. Yogyakarta: Bina Aksara

Aini, Yulfita. 2013. Pengaruh Motivasi internal, eksternal dan Lingkungan Kerja terhadap Kinerja Karyawan Universitas Pasir Pangaraian. Jurnal Ilmiah Cano Ekonomos. Vol.2.No.1. 98-112.

Aziri. B. 2011. Job Satisfaction: A Literature Review. Management Research And Practice. Vol. 3. Issue 4.

Baihaqi, Muhammad Imam. 2013. Pengaruh Kepemimpinan Dan Disiplin Kerja Terhadap Kinerja Pegawai Dengan Kepuasan Kerja Sebagai Variabel Moderating. Naskah Publikasi Universitas Muhammadiyah Surakarta.

Blerkom, M.L.V (2009). Measurement and Statistics for Teachers. New York: Routledge.

Dharmawan, Yusa. 2011. Pengaruh Kompensasi dan Lingkungan Kerja Non Fisik Terhadap Disiplin dan Kinerja Karyawan Hotel Nikki Denpasar. Tesis. Universitas Udayana Denpasar. Bali.

Ghozali, Imam. 2009. Aplikasi Analisis Multivariate Dengan Program SPSS. Edisi Keempat. Semarang: Badan Penerbit Universitas Diponegoro.

Hariandja, Marihot Tua Efendi. 2005. Manajemen Sumber Daya Manusia. Jakarta: PT. Grasindo.

Hasibuan, Melayu. 2012. Manajemen Sumber Daya Manusia, edisi revisi. Jakarta. Bumi Aksara.

Kaur, Surinder dan Jain, Ruchi. 2014. Impact Of Work Environment On Job Satisfaction. International Journal of Scientific And Research Publication. Vol. 4, Issue 2.

Khera, Aman. 2015. Impact Of Employee Empowerment On Job Satisfaction:
An Empirical Analysis of Banks In Chandigarh, (India). International Research Journal of Human Resources and Social Sciences. Vol. 2, 30-39.

Komara, A.K. dan Nelliwati, Euis. 2015. Pengaruh Kompensasi, Motivasi Dan Kepuasan Kerja terhadap Kinerja Pegawai Negeri Sipil (PNS) Di Lingkungan Rumah Sakit Umum Daerah (RSUD) Kota Bandung. Jurnal Ekonomi, Bisnis \& Entrepreneurship Vol. 8, No. 2, 73-85.

Maulina, Syf. Irma. 2013. Efektifitas Pelaksanaan Pemberdayaan Pegawai Negeri Sipil Pada Rumah Sakit Bhayangkara Pontianak. PublikA, Jurnal S-1 Ilmu Administrasi Negara Vol. 2 No. 1.

Nitisemito, Alex Soemadji. 2001. Manajemen Personalia. Jakarta: Ghalia Indonesia.

Nawawi, Handari, H. 1998. Manajemen Sumber Daya Manusia. Yogyakarta, Gajah Mada University Press.

Prawirosentono, Suryadi. 2008, Kebijakan Kinerja, BPFE, Yogyakarta.

Sutrisno, Edy.2011. Manajemen Sumber Daya Manusia. Jakarta:Prenada Media Group.

Rivai, Veithzal dan Ella Jauvani Sagala. 2005. Manajemen Sumber Daya Manusia, Edisi Kedua. Jakarta : Rajawali Pers.

Robbins, Stephen P. 2006, Perilaku Organisasi, Jakarta :Indeks.

Rokhman, Wahibur. 2003. Pemberdayaan Dan Komitmen : Upaya Mencapai Kesuksesan Organisasi Dalam Menghadapi Persaingan Global. Amara Books. Yogyakarta.

Saputro, Arga Bagus. 2015. Pengaruh Pemberdayaan Sumber Daya Manusia Terhadap Kinerja Pegawai Pada Komisi Pemilihan Umum Kota Batu. Jurnal Ilmiah Jurusan Manajemen Fakultas Ekonomi Dan Bisnis Universitas Brawijaya Malang.

Sofyan, Diana Khairani. 2013. Pengaruh Lingkungan Kerja Terhadap Kinerja Pegawai Bappeda. Malikussaleh Industrial Engineering Journal. Vol. 2, 
No. 1, 18-23.

Sugiyono, (2008). Metode Penelitian Kuantitatif, Kualitatifdan R\&D. Bandung Alfabeta

Sutrisno, Edy.(2011). Manajemen Sumber Daya Manusia. Jakarta:Prenada Media Group.

Suryadewi, Putu Choiri et all. 2014.

Pengaruh Pemberdayaan Karyawan Terhadap Kinerja Pada PT. Bali Segara Nusantara. Fakultas Ekonomi dan Bisnis Universitas Pendidikan Ganesha. Vol. 4 No. 1.

Wirawan. (2009). Evaluasi Kinerja Sumber Daya Manusia "Teori, Aplikasi dan Penelitian". Jakarta: Salemba Empat.

Weol, D.H. 2015. Pengaruh Lingkungan Kerja, Pelatihan dan Penempatan Terhadap Kinerja Pegawai Dinas Pendidikan Nasional Provinsi Sulawesi Utara. Jurnal Berkala Ilmiah Efisiensi,Volume 15 No. 05. 